\title{
Effects of physical activity on sclerostin concentrations
}

\author{
Wpływ aktywności fizycznej na stężenia sklerostyny
}

\author{
Małgorzata Janik', Michał Stuss ${ }^{1,2}$, Marta Michalska-Kasiczak1, Anna Jegier ${ }^{3}$, Ewa Sewerynek ${ }^{1,2}$ \\ ${ }^{1}$ Zakład Zaburzeń Endokrynnych i Metabolizmu Kostnego, Katedra Endokrynologii, Uniwersytet Medyczny w Łodzi, Łódź, Polska \\ ${ }^{2}$ Regionalny Ośrodek Menopauzy i Osteoporozy Uniwersyteckiego Szpitala Klinicznego im. WAM — CSW, Łódź, Polska \\ ${ }^{3}$ Zakład Medycyny Sportowej, Uniwersytet Medyczny w Łodzi, Łódż, Polska
}

\begin{abstract}
The aim of the study was an evaluation of the effects of a 12-week physical training programme on the levels of bone turnover markers [Sclerostin, Osteocalcin (OC), C-terminal telopeptide of type I collagen ( $\beta$-CTX)] in serum of women with osteopenia.

Materials and methods: The study included 50 women at the age of 50-75 years with the diagnosis of osteopenia. During the initial 12 weeks (between point 1 and 2), the patients maintained their previous, normal level of physical activity. During subsequent 12 weeks (between point 2 and 3), a programme of exercise was implemented. The programme included the interval training on a bicycle ergometer, three times a week for 36 minutes. During the entire study duration, all the patients received a supplementation of calcium (500 mg) and vit. $\mathrm{D}_{3}(1800 \mathrm{IU})$ once daily. Serum levels of OC, alkaline phosphatase (ALP), $\beta$-CTX and sclerostin were assayed at 3 time points. Results: After the course of the exercise cycle, the OC concentration was increased, sclerostin levels decreased, while no statistical differences were observed in $\beta$-CTX levels vs. the period of physical inactivity. No correlations were found between sclerostin level changes and osteocalcin level changes during the training time, probably because of too small groups. Neither statistically significant were the differences in alkaline phosphatase, calcium and phosphorus levels.

Conclusions: The obtained results emphasise the role of physical training as an effective stimulation method of bone formation processes in women with osteopenia. Sclerostin can be a marker of physical activity. (Endokrynol Pol 2018; 69 (2): 142-149)
\end{abstract}

Key words: physical activity, training, sclerostin, markers

\section{Streszczenie}

Celem pracy była ocena wpływu 12-tygodniowego treningu ruchowego na stężenie markerów obrotu kostnego [Sklerostyny, Osteokalcyny (OC), C-końcowego telopeptydu kolagenu typu I ( $\beta$-CTX)] w surowicy krwi pacjentek z osteopenią.

Materiał i metody: Do badania zostało włączonych 50 pacjentek, w wieku 50-75 lat z rozpoznaniem osteopenii. Przez pierwsze 12 tygodni (punkt 1 i 2) pacjentki prowadziły dotychczasowy poziom aktywności fizycznej. Przez kolejne 12 tygodni (między punktem 2 i 3) został włączony program ćwiczeń fizycznych. Program obejmował trening interwałowy, przeprowadzony na cykloergometrze rowerowym 3 razy w tygodniu, po 36 minut. Wszystkie pacjentki przez cały okres trwania badania pozostawały na suplementacji $500 \mathrm{mg}$ wapnia i 1800 j.m. witaminy $D_{3}$ dziennie. W surowicy krwi w 3 punktach czasowych oznaczano OC, fosfatazę zasadową (ALP), $\beta$-CTX oraz sklerostynę.

Wyniki: Po cyklu treningu fizycznego uzyskano wzrost stężenia OC, spadek sklerostyny, natomiast nie odnotowano istotnych statystycznie różnic $\mathrm{w}$ poziomie markera $\beta$-CTX w porównaniu do okresu bez ćwiczeń. Nie wykazano korelacji pomiędzy zmianami sklerostyny a zmianami osteokalcyny w czasie treningu, prawdopodobnie ze względu na liczebność grup. Różnice w poziomach fosfatazy zasadowej, wapnia i fosforu również nie były istotne statystycznie.

Wnioski: Wyniki badania podkreślają rolę treningu fizycznego, jako skutecznej metody pobudzania procesów kościotworzenia u pacjentek z osteopenią. Sklerostyna może być markerem aktywności ruchowej. (Endokrynol Pol 2018; 69 (2): 142-149)

Słowa kluczowe: aktywność fizyczna, trening, sklerostyna, markery

\section{Introduction}

Mechanical loads, imposed on bones, induce the activation of osteocytes which make $90-95 \%$ of the cell component in adult skeleton [1,2]. Osteocytes effectively identify mechanical signals, being located at small cavities, called lacunas, in the mineralised bone matrix. While transmitting signals to other cells, osteocytes initiate bone tissue rebuilding process $[3,4]$. The mechanism, by which mechanical energy is transformed into electric stimuli, with subsequent biochemical responses, is called mechanotransduction and plays a key role in the process of skeleton adaptation to actual mechanical loads [5].

Biochemical markers of bone turnover that reflect the cellular activity related to the bone formation and bone resorption can be useful in understanding the effects of physical activity on bone [6]. However, many of these markers demonstrate certain limitations, including the lack of specificity towards the osseous tissue, 
an inability to identify metabolic activities of various bone elements. It should also be considered that these markers reflect mainly the function of osteoclasts and osteoblasts, and not the activity of osteocytes, while it is osteocytes which play the key role in maintaining skeleton integrity. Responding to these limitations, the latest studies on bone metabolism markers pay a special attention to sclerostin - the protein produced by osteocytes $[7,8]$.

Sclerostin is being almost exclusively produced by osteocytes. It inhibits the transfer of signals towards activation, proliferation and differentiation of osteoblasts from mesenchymal cells. In case of bone lesions, osteocytes suppress sclerostin secretion in order to activate the processes of osteogenesis and bone repair [9]. Sclerostin overexpression in bone induces osteopenia [10]. Sclerostin stimulates the apoptosis of osteoblasts, thus providing a potential mechanism by which it may inhibit osteogenesis [10,11]. A bone, which is not exposed to mechanical loads, faces the risk of sclerostin concentration increase and, in consequence, a higher incidence rate of osteocyte apoptosis, what enhances the recruitment of osteoclasts and thus bone resorption and loss processes [12]. Immobilisation and lack of physical activity may stimulate the synthesis of this protein [13]. Sclerostin is an inhibitor of the intracellular Wnt signalling pathway $[9,14]$. The signalling via the Wnt pathway is a critical point for bone strength, as it stimulates the differentiation process of cells towards osteoblasts and bone tissue formation, while also suppressing resorption processes. Deactivation of sclerostin activity on the $\mathrm{Wnt} / \beta$-catenin signalling pathway is tantamount to the anabolic effect and thus - to the prevalence of osteogenic mechanisms $[9,15]$.

Osteocalcin (OC) is one of the markers of osteogenesis. OC is produced by mature osteoblasts, but some of circulating $\mathrm{OC}$ is released to circulation by osteoclasts [16]. OC concentration reflects the intensity of osteogenesis and is positively correlated with the histomorphometric parameters of the bone formation process [17].

Physical activity imposes mechanical loads on bone tissue by the combined effect of external forces and muscular contractions which exert a higher impact on bones than other, gravitation-related forces [18]. However, some conditions are to be met in order to make physical conditions a source of positive effects for the bone system. The effectiveness of physical training in the prophylactics of osteoporosis depends, among others, on the intensity of physical exercises, the intervals between repetitions of the same exercise and of particular exercising sessions [19]. Thus a need emerges to design an appropriate training programme to be oriented onto the effective stimulation of osteogenic processes.

\section{Study goals}

The primary goal of the study was an evaluation of the effects of a 12-week interval training programme on sclerostin protein concentrations in serum, together with an assessment of the training influence on the concentration of bone metabolism markers: OC and C-terminal Telopeptide type 1 Collagen $(\beta$-CTX) in serum in female patients with low bone mass. Another (secondary) goal of the study was an evaluation of the relationships between sclerostin and OC concentrations and BMD.

\section{Materials and methods}

The study was carried out between January 2012 and December 2014. Physical activity trainings and blood collections were performed between September and April periods.

The participants included 50 female patients. Their age was varying between 50 and 75 years (see Table I). Inclusion criteria: female gender, clinical diagnosis - osteopenia (following the guidelines of the World Health Organisation for T-Score from -1.0 to -2.5 SD in proximal femur and/or lumbar spine densitometry); low or moderate physical activity, assessed by IPAQ — International Physical Activity Questionnaire [20]. Exclusion criteria: male gender; concomitant diseases (active inflammatory diseases, psychic diseases, impaired functionality of a motor organ, precluding any possibility to carry out a physiotherapy programme, BMD-affecting diseases); intake of bone metabolism affecting drugs, including, among others: bisphosphonates, strontium ranelate, glucocorticoids; disqualification by exercise test results.

The study lasted 24 weeks. During the first 12 weeks, the patients remained at the previous level of physical activity (between the 1 st and the 2 nd time point). During the other 12 weeks, a cardio workout programme was introduced (between the 2 nd and the 3rd time point (see Figure 1).

Before the study, all the patients were submitted to an exercise test at the Department of Sports Medicine. Out of the fifty qualified patients, the study project was completed by 41 women $(82 \%)$. The causes of withdrawal included: motor organ pains during the exercise programme $(n=2)$, disease $(n=4)$, personal $(\mathrm{n}=3)$. During the entire study duration, all the patients received a supplementation programme, including calcium (500 mg) and vit. $\mathrm{D}_{3}$ (1800 IU) once daily.

\section{Biochemical studies}

Blood sampling was carried out fasting at 9:00 am to minimize circadian effects. Blood samples after the 12-weeks of interval physical training on a bicycle 
Table I. General characteristics of study population

Tabela I. Ogólna charakterystyka populacji badanej

\begin{tabular}{|c|c|c|}
\hline \multirow[b]{2}{*}{ Feature } & \multicolumn{2}{|c|}{ Studied group $(n=50)$} \\
\hline & Mean & SD \\
\hline Age (years) & 64.8 & 5 \\
\hline BMI [kg/sq.m.] & 26.1 & 3.46 \\
\hline WHR & 0.8 & 0.07 \\
\hline \multicolumn{3}{|l|}{ T-Score } \\
\hline - lumbar spine $\left(\mathrm{L}_{2}-\mathrm{L}_{4}\right)$ & -2.04 & 0.69 \\
\hline — neck femur & -1.95 & 0.32 \\
\hline \multicolumn{3}{|l|}{$\operatorname{BMD}\left(\mathrm{g} / \mathrm{cm}^{2}\right)$} \\
\hline - lumbar spine $\left(\mathrm{L}_{2}-\mathrm{L}_{4}\right)$ & 0.9 & 0.28 \\
\hline — neck femur & 0.78 & 0.07 \\
\hline $\mathrm{Ca}[\mathrm{mmol} / \mathrm{l}]$ & 2.43 & 0.12 \\
\hline $\mathrm{P}[\mathrm{mmol} / \mathrm{l}]$ & 1.14 & 0.13 \\
\hline $\mathrm{ALP}[\mathrm{U} / \mathrm{I}]$ & 75.24 & 14.85 \\
\hline Vitamin $D_{3}[\mathrm{ng} / \mathrm{ml}]$ & 23.7 & 11.96 \\
\hline
\end{tabular}

ergometer were collected next day after the last training session.

Biochemical assays, including bone turnover marker concentrations, employed the following methods and kits: - Alkaline Phosphatase - by the colorimetric method, supported by Olympus kits and analyser (of Olympus Life and Material Sciences, Ireland), at wave lengths of 410 and $480 \mathrm{~nm}$, following the manufacturer's recommendations.

- Osteocalcin (OC) and $\beta$-CrossLaps ( $\beta$-CTX) by the electrochemiluminescence method, using an Elecsys 2010 analyser (Roche Diagnostics) and kits of Roche Diagnostics (Penzberg, Germany), following the manufacturer's recommendations.

- Sclerostin by the ELISA Enzyme-Linked Immunosorbent Assay) with kits of Biomedica Gruppe (Vienna, Austria) and a Metertech 8960 spectrophotometer (Metertech Inc., Taiwan). The assays were carried out at wavelengths of $450 \mathrm{~nm}$, using a reference filter of $620 \mathrm{~nm}$, following the instructions of the Elisa's manufacturer. The intra- and inter-assay coefficients of variation (CVs) were $\leq 7 \%$ and $\leq 10 \%$ and the limit of detection was $0.07 \mathrm{ng} / \mathrm{ml}$.

- Total calcium in serum - by quantitative colorimetric assay at wavelengths of 660 and $700 \mathrm{~nm}$, using kits of Beckman Coulter (Beckman Coulter Inc., USA) and an Olympus analyser (Olympus Life and Material Sciences, Ireland), following the manufacturer's recommendations.

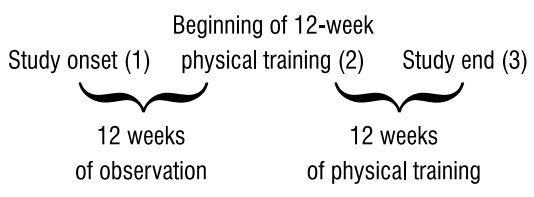

Figure 1. Study schema - 1. Inclusion into study - baseline; 2. After 12 weeks of observation. Time point when physical activity was started; 3. After 12 weeks of physical activity

Rycina 1. Schemat badania - 1. Wtaczenie do badania początek; 2. Po 12 tygodniach obserwacji. Moment rozpoczęcia programu aktywności fizycznej 3. Po 12 tygodniach aktywności fizycznej

- Inorganic phosphorus content in serum, by the photometric method, at wavelengths of 340 and $380 \mathrm{~nm}$, using kits and an analyser of Olympus (Olympus Life and Material Sciences, Ireland), according to the manufacturer's protocol.

- Total vitamin D (25 hydroxyvitamin D3 and 25 hydroxyvitamin D2) by the electrochemiluminescence method, using an Elecsys 2010 analyser (Roche Diagnostics) and kits of Roche Diagnostics (Penzberg, Germany), following the manufacturer's recommendations.

- The serum, used for sclerostin, $\beta$-CTX and OC assays, was frozen immediately after centrifuging and stored in temperature of $-70^{\circ} \mathrm{C}$ until assayed. The other laboratory tests, i.e., serum calcium and phosphate levels, as well as the concentration of alkaline phosphatase, were measured on an ongoing basis in the morning and in fasting condition.

\section{Densitometric examination}

Bone mineral density studies were carried out by the dual-energy x-ray absorptiometry (DXA) method, using a GE Lunar Prodigy device. The minimum acceptable precision for technologists in our facility does not exceed the values: $1.9 \%$ (LSC $=5.3 \%$ ) for Lumbar Spine, $1.8 \%(\mathrm{LSC}=5.0 \%)$ for Total Hip and $2 \%(\mathrm{LSC}=5.5 \%)$ for Femoral Neck.

\section{Motor activity program}

The biochemical tests were repeated after 12 weeks from the initial studies, using the same testing tools. Then, the patients, qualified to the programme, began the 12-week training of physical activity. It was an interval training, performed on a MONARK 915E testing bike ergometer. Training sessions were held three times a week. Each session lasted 36 minutes and consisted of 5 stages, preceded by a 4-minute warming-up (the total exercise time, including the warming-up, was 40 minutes). The training method was based on patient's 4-minute exercise, followed by a 2-minute rest phase. 
All patients were performed stress test in order to qualify to participate in the study, as well as to determine the exercise intensity. On the basis of this test, all patients started from the same level of load (measured in Watts), according to the following scheme: warm-up (30 Watts) - a two-minute break - exercise (45 Watts) - a twominute break - exercise (60 Watts) - two-minute break - exercise (45 Watts) - two-minute break — exercise (30 Watts) - end with no load. All participants started with the same maximum load that was 60 Watts. In case of patients that were obtaining a better physical fitness during the training, (reduction of heart rate during exercise in comparison to baseline) physical load was being increased by 25 Watts at every stage of training. After completion of the study patients achieved the following maximum loads: 75 Watts -16 patients; 90 Watts -17 patients. In case of 7 patients the maximum load remained unchanged. The entire training period was continuously monitored by ECG and the arterial pressure was measured each six-minute period by the sphygmomanometric method on the left arm.

\section{Statistical analysis}

Distributions of variables at given time points and their conformity with normal distribution were examined in the first stage of analysis. The normality Shapiro-Wilk test was applied to verify the hypothesis of the normality of distributions of particular variables. In cases, where there were no grounds to refuse the hypothesis that a given distribution is conformable with the normal distribution, the ANOVA test was applied with repeated measurements. While in case of any incompatibility of distribution with the normal distribution, the Friedman ANOVA test was used (or the Wilcoxon pair sequence test in case when two points were compared).

\section{Results}

\section{Results of physical activity level evaluation}

All the patients were qualified on the basis of a questionnaire to a group, demonstrating a moderate level of physical activity.

Based on the analysed data, significant differences were observed between vitamin $\mathrm{D}_{3}$ concentrations before and after the study (see Table II). Significantly higher values were obtained after the 12-week training on the testing bike ergometers vs. the values before the study ( 1 vs. 3 ) p $<0.001 ; 37.34 \%$ and before the onset of the 12 -week interval training ( 2 vs. 3 ) $\mathrm{p}<0.001 ; 26.8 \%$.

Significant differences in Ca levels in serum were observed between time point (2) and time point (3). Prior to the 12-week physical training, Ca levels were significantly higher, when compared with the results after the 12-week training on the testing bike ergometers ( 2 vs. 3 ) p $<0.01 ; 3.23 \%$ (see Table II).

Based on obtained data, statistically significantly higher serum OC concentrations were observed after the 12-week training period on the testing bike ergometers in comparison with OC concentration values before the study (1 vs. 3 ) p $<0.005 ; 9.09 \%$ and before the training ( 2 vs. 3 ) $\mathrm{p}<0.001 ; 13.05 \%$ (see Figure 2). A drop down of OC level was noted in six cases after training only.

No significant differences were obtained in $\beta$-CTX variable levels at the analysed time points (see Figure 3).

Sclerostin concentrations were significantly lower after the 12-week physical training vs. its concentrations before the study ( 1 vs. 3 ) p < 0.001 ; by $12.04 \%$ and before the training on the testing bike ergometers ( 2 vs. 3 ) p < 0.001 ; by $12.44 \%$ (see Figure 4 ). An increase of sclerostin concentration was observed in four cases after training only.

Table II. Analysis of total vitamin D, alkaline phosphatase, calcium, phosphate, osteocalcin, $\beta$-CTX and sclerostin serum concentrations in 3 time points of the study

Tabela II. Analiza stężeń witaminy D, fosfatazy zasadowej, wapnia i fosforanów, osteokalcyny, $\beta$-CTX oraz sklerostyny w surowicy $w 3$ badanych punktach czasowych badania

\begin{tabular}{|c|c|c|c|c|c|c|c|c|c|}
\hline & \multicolumn{2}{|c|}{$\begin{array}{c}\text { (1) } \\
\text { Baseline }\end{array}$} & \multicolumn{2}{|c|}{$\begin{array}{c}\text { (2) after } 12 \text { weeks } \\
\text { without physical } \\
\text { training }\end{array}$} & \multirow[t]{2}{*}{$\begin{array}{l}\text { p level (1 } \\
\text { vs. 2) }\end{array}$} & \multicolumn{2}{|c|}{$\begin{array}{c}\text { (3) after } 12 \text { weeks } \\
\text { of interval physical } \\
\text { training }\end{array}$} & \multirow[t]{2}{*}{$\begin{array}{c}\text { p level (2 } \\
\text { vs. 3) }\end{array}$} & \multirow[t]{2}{*}{ p level (1 vs. 3) } \\
\hline & Mean & SD & Mean & SD & & Mean & SD & & \\
\hline Vitamin D [ng/mL] & 23.70 & 11.96 & 25.67 & 12.36 & $p<0.0001$ & 32.55 & 10.22 & $p<0.001$ & $p<0.001$ \\
\hline $\mathrm{ALP}[\mathrm{U} / \mathrm{L}]$ & 75.24 & 14.85 & 77.12 & 16.68 & NS & 75.95 & 16.58 & NS & NS \\
\hline $\mathrm{Ca}[\mathrm{mmol} / \mathrm{L}]$ & 2.43 & 0.12 & 2.48 & 0.10 & NS & 2.40 & 0.18 & $p<0.01$ & NS \\
\hline $\mathrm{P}[\mathrm{mmol} / \mathrm{L}]$ & 1.14 & 0.13 & 1.18 & 0.11 & NS & 1.14 & 0.14 & NS & NS \\
\hline Ostecalcin [ng/mL ] & 21.67 & 8.01 & 20.91 & 7.25 & NS & 23.64 & 8.43 & $p<0.001$ & $p<0.005$ \\
\hline$\beta$-CTX [ng/mL] & 0.40 & 0.21 & 0.41 & 0.19 & NS & 0.39 & 0.20 & NS & NS \\
\hline Sclerostin [ng/mL] & 275.82 & 38.15 & 277.07 & 38.35 & NS & 242.60 & 43.04 & $p<0.001$ & $p<0.001$ \\
\hline
\end{tabular}

NS - not significant 


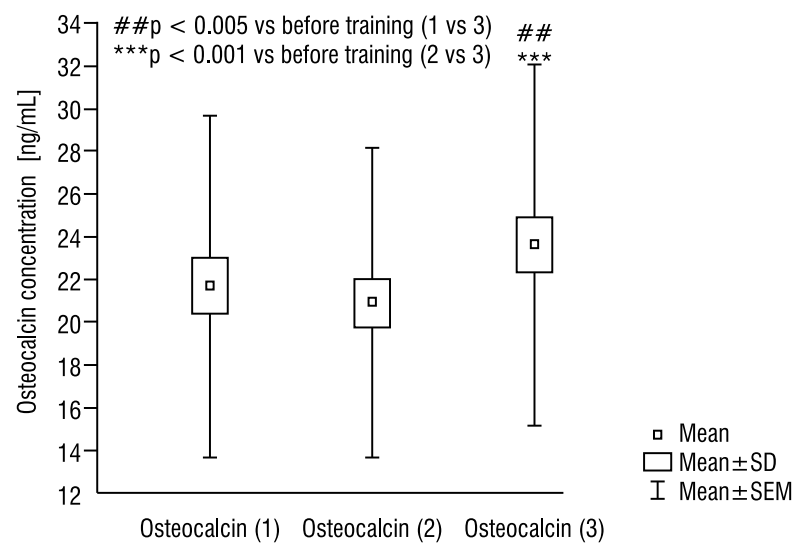

Figure 2. The changes of osteocalcin concentration for whole population in 3 time study points of the study

Rycina 2. Zmiany stężeń osteokalcyny w populacji badanej $w 3$ badanych punktach czasowych

\section{Correlations between absolute (differences) and relative changes}

Because the distributions of absolute and relative differences (time points 1 and 3 and time points 2 and 3 ) for OC and sclerostin significantly differed from normal distribution ( $p<0.05$ for the Shapiro-Wilk test), the Spearman's rank correlation test was used for the analysis of the existing correlations.

No significant correlations were observed during the performed study between the relative changes of osteocalcin concentrations at time points 1 and 3 and 2 and 3 and the corresponding absolute changes of sclerostin concentrations between time points 1 and 3 and 2 and 3 , respectively ( $p>0.05$ ) (data not shown).

\section{Discussion}

Bone metabolic markers may be useful in the diagnosis and monitoring of not only osteoporosis [21, 22], but may also be applied in other diseases that secondarily lead to bone metabolic disorders [23-25]. In our study we have assessed the effect of physical activity on changes in sclerostin and other known bone metabolism markers levels.

Significantly higher values of vitamin $\mathrm{D}_{3}$ were obtained after the 12-week training on the testing bike ergometers vs. the values before the study ( 1 vs. 3 ; $\mathrm{p}<0.001)$ and before the onset of the 12-week interval training ( 2 vs. $3 ; p<0.001)$. All the patients were supplemented with calcium and vitamin $\mathrm{D}$ prior to enrollment and all of them declared good compliance in terms of above supplementation, but it is possible that the inclusion of the study led to its further improvement (greater involvement in the therapeutic process) and gradual increase of total serum vitamin D level.

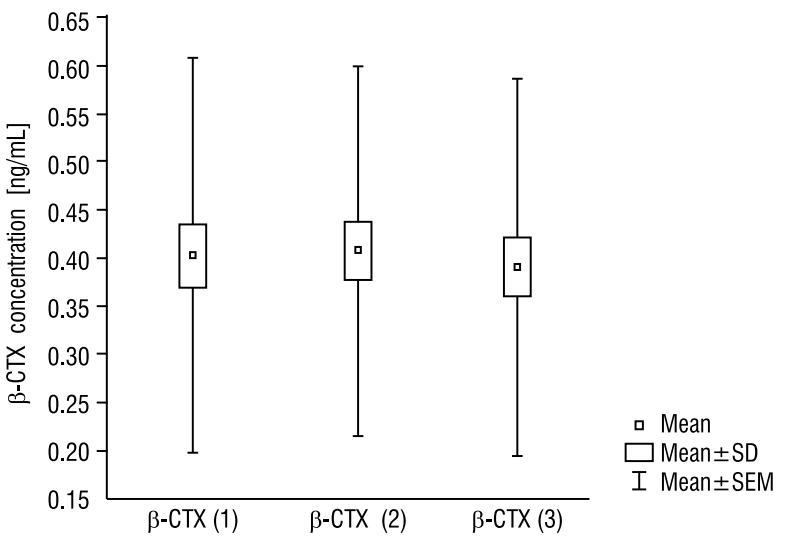

Figure 3. The changes of $\beta$-CTX concentration for whole population in 3 time study points of the study

Rycina 3. Zmiany stężeń $\beta-C T X$ w populacji badanej w 3 badanych punktach czasowych

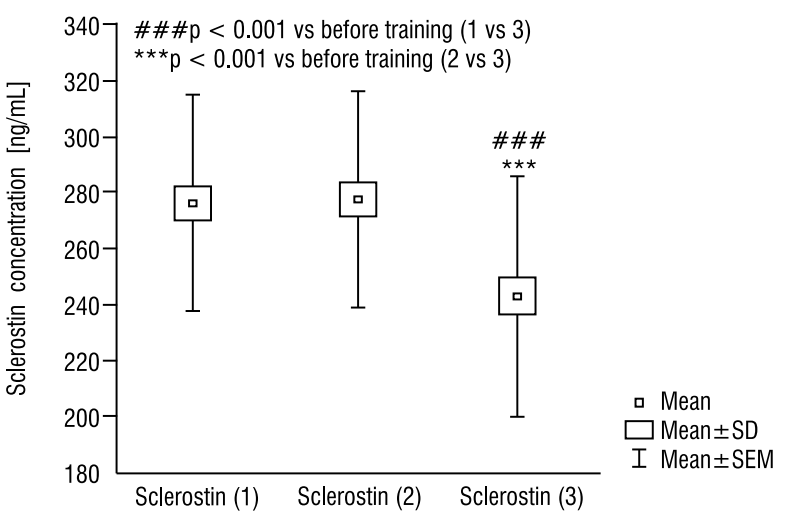

Figure 4. The changes of sclerostin concentration for whole population in 3 time points of the study

Rycina 4. Zmiany stężen sklerostyny w populacji badanej w 3 badanych punktach czasowych

Significantly lower serum Ca levels after training were probably associated with higher calcium utilization, as well as with changes in electrolyte concentrations and acid-base balance. The above changes depends on intensity of physical activity and load [26].

Based on obtained data, statistically significantly higher serum OC concentrations were observed after the 12-week training period on the testing bike ergometers in comparison with $\mathrm{OC}$ concentration values before the study $(\mathrm{p}<0.001)$. No significant differences were obtained in $\beta$-CTX variable levels at the analysed time points. In a study by Adami et al. [27], similar results were obtained, concerning OC and $\beta$-CTX concentration changes after the physical activity programme in premenopausal women was over.

In a study by Pernambuco et al. [28] the influence of physical activity (aerobic in water) on BMD and serum 
osteocalcin was evaluated, as well as the "stand up and go" test in 82 postmenopausal women with low BMD values. The patients were randomly divided into two groups: the water aerobic group - exercises twice a week during 8 months and a control group without regular exercises. After the study was over, a significant increase in serum OC levels was observed in the group of physically active patients, similarly as in our study. No statistically significant BMD differences were seen between the two groups.

There are relatively few studies about the effects of physical training on sclerostin levels [6]. Ardawi et al. [29] performed an evaluation of physical activity effects on sclerostin and bone turnover marker (BTM) levels in serum and on BMD. Women at the age of 20-49 years, were divided into two groups: one group undertaking physical activity $(\mathrm{PA})>120$ minutes 4 times a week $(\mathrm{n}=58)$ and a control group $<30$ minutes of physical exercises a week $(n=62)$. An 8-week programme of physical activity, undertaken by the active group, provided decreases in serum sclerostin concentrations (by 33.9\%, $p=0.0001)$ and increased serum levels of osteogenesis markers. The observed increased values of OC, ALP and procollagen type I N-terminal propeptide (PINP) were significantly higher in PA group. Thus, the authors of above study obtained convergent results to ours. Huovinen et al. [30] analyzed the effects of resistance training on the elderly patients with reduced muscle strength. After 16 weeks of intervention a significant increase in sclerostin and OC was noted, unlike the other markers (CTX and PINP).

Changes in bone markers levels may also be dependent on the primary BMD and kind of physical activity (discipline). In the study of Ahn et al. [31] after a 12-week exercise programme a significantly higher increase in OC concentration was seen in the group of female osteoporotic patients than in a group of women with normal BMD. Lombardi et al. [32] showed that intensive cycling is associated with a decrease in total OC serum concentrations and an increase in the percentage of its undercarboxylated fraction. The authors emphasized that the results were affected by a large individual variability. In another study [33] of 48 postmenopausal women with low BMD there were no differences in the concentrations of CTX and OC between the group of patients after a 10-week groupbased step aerobics and the control group. The different results were obtained by Mohr et al. [34], who analyzed influence of 15 weeks of different forms of training on female population. In this study, a significant increase in bone resorption (CTX) and formation markers (OC and PINP) were obtained only in a subpopulation of women training football in comparison to the control group and swimming subpopulation, but before drawing the conclusions one should remember that these were premenopausal women. Study on a similar population of Polish women showed no difference between the concentrations of OC and CTX between the population of equestrians and the control group [35].

Some clinical data suggest that circulating sclerostin is associated with BMD in older women and men. In one study [36], a significant negative correlation was demonstrated between serum sclerostin and OC concentrations and BMD. By contrast, no correlation was observed in our study between sclerostin and OC concentration changes. It should be emphasised that the first 12 weeks in our study provided a control group for the later training cycle and the BMD evaluation was done for qualification at the moment, when the patients were included into the study, thus it is not possible to determine BMD changes. In several studies by other authors, higher BMD was demonstrated in groups of exercising women. Bergstrom et al. [37] analyzed BMD and BTM changes in a group of patients undertaking motor activity for 12 weeks (30-minute marches three times a week and one 1-hour aerobic training). After the training programme was over, a significant BMD increase was demonstrated in the femoral neck. CTX and ALP, bone turnover markers, revealed a slightly falling (insignificant) tendency in comparison to the control group.

A statistically significant BMD rise in the lumbar spine and in the neck was also achieved in a study of Gaudio et al. [38] after the physical activity. Additionally, a significant serum sclerostin increase was demonstrated in a group of immobilised postmenopausal female patients vs. a control group - physically active women - $(p<0.0001)$ - with higher bone turnover and prevalence of CTX vs. ALP. In the immobilised group, a negative correlations between sclerostin and ALP ( $\mathrm{r}=-0.911 ; \mathrm{p}<0.0001)$ was observed and positive correlation with CTX $(r=0.391, p=0.012)$. Those observations emphasise the important role of physical activity in bone formation processes [38].

The literature reports on the sclerostin serum levels in athletes compared with non-active individuals are frequently inconclusive and call into question whether small differences in sclerostin levels are of physiologic or clinical significance. Gombos et al. [6] found that sclerostin levels increased in a similar group of women as in our study, who underwent a program of walking exercise or resistance exercise, compared to a control group. Similar results were presented by Zagrodna et al. [39] who reported that male athletes had significantly higher sclerostin levels than age-matched sedentary men. Also, Lombardi et al. [40] investigating sclerostin concentrations in elite athletes, found higher sclerostin levels in males participating in weight-bearing 
disciplines than in those who participated in nonweight-bearing sports. It can be assumed that different types of physical activity result in differences in sclerostin levels. Moreover, Lombardi et al. [40], unlike to us, showed that individuals with low levels of physical activity have lower serum concentrations of sclerostin than professional rugby players or endurance athletes.

At present, the prophylactics of osteoporotic fractures is mainly based on pharmacotherapy which has proven effective in reducing fracture risks [41]. However, high doses of bisphosphonates, despite BMD improvement, may lead to accumulation of micro traumas and decreased ability to absorb energy by the trabecular bone, what may paradoxically lead to higher fracture risks [41]. Contrary to the therapy with medicinal agents, mechanical loads, achieved by properly targeted physical exercise, may lead to a considerable improvement of such properties as mechanical strength - i.e., the force level necessary to cause bone fracture. Still, physical exercises should never replace pharmacological therapy of osteoporosis, while - when properly planned - they improve a number of features and properties, regardless of BMD, including the sense of balance, gait mechanics, agility, muscular strength, resistance to fatigue, where none of the features depends on bisphosphonate therapy [41].

One of the limitations in our study was the necessity to participate in each training session, 3 times a week for 12 weeks, which was unacceptable by some of our patients. We are also aware of the small size of our population. Our knowledge of the relationships between specific forms of physical effort and bone formation processes is rather limited. In the above described studies physical activity was evaluated in non-uniform ways and the studied populations differed significantly from each other. Based on reported study, an adopted programme of physical activity seems to be an effective way to stimulate osteogenesis processes in female patients with low bone mass.

Muscular contractions stimulate the formation processes of bones on their surface (periosteum), leading to an increased resistance to bending forces. It may then be more important than the BMD increase itself. Periosteal increase may falsify the actual effects on BMD, as it increases bone cross-section area, consequently increasing the denominator, used to calculate bone mineral density (i.e., bone mineral content/studied area). The example comes from studies on osteoporotic fractures [42] in which, women achieved higher body mass by increased bone strength, while reducing femoral bone BMD values. Therefore, the value of exercises in osteoporosis prophylactics and therapy cannot be fully evaluated by their effects on BMD [42].
Summing up, the 12-week interval training on cycle ergometer bikes increased serum OC, while decreasing serum sclerostin concentrations. The bone turnover markers may be helpful in the evaluation of the efficacy of carried out physical activity, but we are aware that they have some limitations. OC plays also role in energy metabolism, e.g. physical activity (energy expenditure) and the changes of its concentrations could be partially independent of bone formation. Sclerostin concentration fall after properly planned physical training may play a significant function of osteoblastogenesis stimulator, and its serum concentrations may be considered as a potentially valuable parameter in the monitoring and forecasting of further therapy course, while strength training may be perceived as a multidirectional way of therapy in cases of osteopenia and postmenopausal osteoporosis.

\section{Conclusions}

The obtained results emphasise the role of physical activity as an effective stimulation method of bone formation processes in female patients with low bone mass, with many combined advantages for patient health. Sclerostin can be a marker of physical activity.

\section{Acknowledgements and funding source}

The study was funded by Grant No.2011/01/N/NZ7/01331 from the National Science Centre; Medical University Project No. 507-10-031

\section{Disclosure of conflicts of interest}

All authors certify that have no financial interests such as employment, stock ownership, honoraria, paid expert testimony, as well as any personal relationships, academic competition, and intellectual passion which may inappropriately influence their actions.

All funding sources supporting the work and all institutional or corporate affiliations are acknowledged in a footnote.

All authors have had full access to all the data in the study (if applicable) and thereby accept full responsibility for the integrity of the data and the accuracy of the data analysis.

\section{References}

1. Schwab P, Scalapino K. Exercise for bone health: rationale and prescription. Curr Opin Rheumatol. 2011; 23(2): 137-141, doi: 10.1097/ BOR.0b013e3283434501, indexed in Pubmed: 21178629.

2. Kohrt WM, Barry DW, Schwartz RS. Muscle forces or gravity: what predominates mechanical loading on bone? Med Sci Sports Exerc. 2009; 41(11): 2050-2055, doi: 10.1249/MSS.0b013e3181a8c717, indexed in Pubmed: 19812511.

3. Czarkowska-Paczek B, Wesołowska K, Przybylski J. [Physical exercise prevents osteoporosis]. Przegl Lek. 2011; 68(2): 103-106, indexed in Pubmed: 21751519. 
4. Taylor AF, Saunders MM, Shingle DL, et al. Mechanically stimulated osteocytes regulate osteoblastic activity via gap junctions. Am J Physiol Cell Physiol. 2007; 292(1): C545-C552, doi: 10.1152/ajpcell.00611.2005, indexed in Pubmed: 16885390.

5. Liu C, Zhao Y, Cheung WY, et al. Effects of cyclic hydraulic pressure on osteocytes. Bone. 2010; 46(5): 1449-1456, doi: 10.1016/j.bone.2010.02.006, indexed in Pubmed: 20149907.

6. Gombos GC, Bajsz V, Pék E, et al. Direct effects of physical training on markers of bone metabolism and serum sclerostin concentrations in older adults with low bone mass. BMC Musculoskelet Disord. 2016; 17: 254, doi: 10.1186/s12891-016-1109-5, indexed in Pubmed: 27278385.

7. Marcus R. Mechanisms of Exercise Effects on Bone. In: Bilezikian JP, Raisz LG, Rodan GA. ed. Principles of bone biology 2nd. Academic Press, San Diego 2002: 1477-1488.

8. Garnero P. New developments in biological markers of bone metabolism in osteoporosis. Bone. 2014; 66: 46-55, doi: 10.1016/j.bone.2014.05.016 indexed in Pubmed: 24909537.

9. Pawlak-Buś K, Leszczyński P. Sklerostyna-nowy cel terapii anabolicznej niskiej masy kostnej. Reumatologia. 2010; 48: 183-187.

10. van Bezooijen RL, ten Dijke P, Papapoulos SE, et al. SOST/sclerostin an osteocyte-derived negative regulator of bone formation. Cytokine Growth Factor Rev. 2005; 16(3): 319-327, doi: 10.1016/j.cytogfr.2005.02.005, indexed in Pubmed: 15869900.

11. Sutherland MK, Geoghegan JC, Yu C, et al. Sclerostin promotes the apoptosis of human osteoblastic cells: a novel regulation of bone formation. Bone. 2004; 35(4): 828-835, doi: 10.1016/j.bone.2004.05.023, indexed in Pubmed: 15454089

12. Aguirre JI, Plotkin LI, Stewart SA, et al. Osteocyte apoptosis is induced by weightlessness in mice and precedes osteoclast recruitment and bone loss. J Bone Miner Res. 2006; 21(4): 605-615, doi: 10.1359/jbmr.060107, indexed in Pubmed: 16598381.

13. Leblanc AD, Schneider VS, Evans HJ, et al. Bone mineral loss and recovery after 17 weeks of bed rest. J Bone Miner Res. 1990; 5(8): 843-850, doi: 10.1002/jbmr.5650050807, indexed in Pubmed: 2239368.

14. Choi HY, Dieckmann M, Herz J, et al. Lrp4, a novel receptor for Dickkopf 1 and sclerostin, is expressed by osteoblasts and regulates bone growth and turnover in vivo. PLoS One. 2009; 4(11): e7930, doi: 10.1371/journal. pone.0007930, indexed in Pubmed: 19936252.

15. Ott SM. Sclerostin and Wnt signaling--the pathway to bone strength J Clin Endocrinol Metab. 2005; 90(12): 6741-6743, doi: 10.1210/jc.20052370, indexed in Pubmed: 16330810.

16. Lee $\mathrm{NaK}$, Sowa H, Hinoi E, et al. Endocrine regulation of energy metabolism by the skeleton. Cell. 2007; 130(3): 456-469, doi: 10.1016/j. cell.2007.05.047, indexed in Pubmed: 17693256.

17. Szulc P. The role of bone turnover markers in monitoring treatment in postmenopausal osteoporosis. Clin Biochem. 2012; 45(12): 907-919, doi: 10.1016/j.clinbiochem.2012.01.022, indexed in Pubmed: 22330940.

18. Matsuo K. Cross-talk among bone cells. Curr Opin Nephrol Hypertens. 2009; 18(4): 292-297, doi: 10.1097/MNH.0b013e32832b75f1, indexed in Pubmed: 19395964.

19. Rubin C, Turner AS, Bain S, et al. Anabolism. Low mechanical signals strengthen long bones. Nature. 2001; 412(6847): 603-604, doi: 10.1038/35088122, indexed in Pubmed: 11493908.

20. Questionnaire of Physical Activity, Polish version. Http://www.academia. edu/19229070/Mi\% C4\% 99dzynarodowy IPAQ.

21. Stuss M, Sewerynek E, Król I, et al. Assessment of OPG, RANKL, bone turnover markers serum levels and BMD after treatment with strontium ranelate and ibandronate in patients with postmenopausal osteoporosis. Endokrynol Pol. 2016; 67(2): 174-184, doi: 10.5603/EP.a2016.0014, indexed in Pubmed: 26884284.

22. Zalecenia postępowania diagnostycznego i leczniczego w osteoporozie. Medycyna Praktyczna 2013.

23. Ostrowska Z, Ziora K, Oświęcimska J, et al. Vaspin and selected indices of bone status in girls with anorexia nervosa. Endokrynol Pol. 2016 67(6): 599-606, doi: 10.5603/EP.2016.0070, indexed in Pubmed: 28042653.

24. Ostrowska Z, Ziora K, Oświęcimska J, et al. TGF- $\beta 1$, bone metabolism, osteoprotegerin, and soluble receptor activator of nuclear factor-kB ligand in girls with anorexia nervosa. Endokrynol Pol. 2016; 67(5): 493-500, doi: 10.5603/EP.a2016.0059, indexed in Pubmed: 27828689.

25. Gołąbek K, Ostrowska Z, Ziora K, et al. Association between omentin-1, bone metabolism markers, and cytokines of the RANKL/RANK/OPG sys- tem in girls with anorexia nervosa. Endokrynol Pol. 2015; 66(6): 514-520, doi: 10.5603/EP.2015.0063, indexed in Pubmed: 26662650

26. Deogenov VA, Zorbas YG, Kakuris KK, et al. The impact of physica exercise on calcium balance in healthy subjects during prolonged hypokinesia. Nutrition. 2009; 25(10): 1029-1034, doi: 10.1016/j.nut.2009.02.014, indexed in Pubmed: 19729128.

27. Adami S, Gatti D, Viapiana O, et al. BONTURNO Study Group. Physical activity and bone turnover markers: a cross-sectional and a longitudinal study. Calcif Tissue Int. 2008; 83(6): 388-392, doi: 10.1007/s00223-0089184-8, indexed in Pubmed: 18949504.

28. Pernambuco CS, Borba-Pinheiro CJ, Vale RG, et al. Functional autonomy, bone mineral density (BMD) and serum osteocalcin levels in older female participants of an aquatic exercise program (AAG). Arch Geronto Geriatr. 2013; 56(3): 466-471, doi: 10.1016/j.archger.2012.12.012, indexed in Pubmed: 23375799.

29. Ardawi MSM, Rouzi AA, Qari MH. Physical activity in relation to serum sclerostin, insulin-like growth factor-1, and bone turnover markers in healthy premenopausal women: a cross-sectional and a longitudinal study. J Clin Endocrinol Metab. 2012; 97(10): 3691-3699, doi: 10.1210/ jc.2011-3361, indexed in Pubmed: 22865898

30. Huovinen V, Ivaska KK, Kiviranta R, et al. Bone mineral density is increased after a 16-week resistance training intervention in elderly women with decreased muscle strength. Eur J Endocrinol. 2016; 175(6): 571-582, doi: 10.1530/EJE-16-0521, indexed in Pubmed: 27634943 .

31. Ahn N, Kim K. Effects of 12-week exercise training on osteocalcin, highsensitivity C-reactive protein concentrations, and insulin resistance in elderly females with osteoporosis. J Phys Ther Sci. 2016; 28(8): 2227-2231, doi: 10.1589/jpts.28.2227, indexed in Pubmed: 27630402.

32. Lombardi G, Lanteri P, Graziani R, et al. Bone and energy metabolism parameters in professional cyclists during the Giro d'Italia 3-weeks stage race. PLoS One. 2012; 7(7): e42077, doi: 10.1371/journal.pone.0042077, indexed in Pubmed: 22848709.

33. Wen HJ, Huang TH, Li TL, et al. Effects of short-term step aerobic exercise on bone metabolism and functional fitness in postmenopausal women with low bone mass. Osteoporos Int. 2017; 28(2): 539-547, doi: 10.1007/s00198-016-3759-4, indexed in Pubmed: 27613719.

34. Mohr M, Helge EW, Petersen LF, et al. Effects of soccer vs swim training on bone formation in sedentary middle-aged women. Eur J Appl Physiol. 2015; 115(12): 2671-2679, doi: 10.1007/s00421-015-3231-8, indexed in Pubmed: 26255288.

35. Kaczmarek A, Nowak A, Leszczynski P. Bone Mineral Density and Biochemical Markers of Bone Metabolism in Women Engaging in Recreational Horseback Riding. J Phys Act Health. 2016; 13(5): 520-524, doi: 10.1123/jpah.2015-0131, indexed in Pubmed: 26529180.

36. Clarke BL, Drake MT. Clinical utility of serum sclerostin measurements Bonekey Rep. 2013; 2: 361, doi: 10.1038/bonekey.2013.95, indexed in Pubmed: 24578825.

37. Bergström I, Parini P, Gustafsson SA, et al. Physical training increases osteoprotegerin in postmenopausal women. J Bone Miner Metab. 2012; 30(2): 202-207, doi: 10.1007/s00774-011-0304-6, indexed in Pubmed: 21823052.

38. Gaudio A, Pennisi P, Bratengeier C, et al. Increased sclerostin serum levels associated with bone formation and resorption markers in patients with immobilization-induced bone loss. J Clin Endocrino Metab. 2010; 95(5): 2248-2253, doi: 10.1210/jc.2010-0067, indexed in Pubmed: 20305005.

39. Zagrodna A, Jóźków P, Mędraś M, et al. Sclerostin as a novel marker of bone turnover in athletes. Biol Sport. 2016; 33(1): 83-87, doi: 10.5604/20831862.1194125, indexed in Pubmed: 26929475.

40. Lombardi G, Lanteri P, Colombini A, et al. Sclerostin concentrations in athletes: role of load and gender. J Biol Regul Homeost Agents. 2012 26(1): 157-163, indexed in Pubmed: 22475109.

41. Allen MR, Iwata K, Phipps R, et al. Alterations in canine vertebral bone turnover, microdamage accumulation, and biomechanical properties following 1-year treatment with clinical treatment doses of risedronate or alendronate. Bone. 2006; 39(4): 872-879, doi: 10.1016/j.bone.2006.04.028, indexed in Pubmed: 16765660

42. Beck TJ, Kohlmeier LA, Petit MA, et al. Confounders in the association between exercise and femur bone in postmenopausal women. Med Sci Sports Exerc. 2011; 43(1): 80-89, doi: 10.1249/MSS.0b013e3181e57bab, indexed in Pubmed: 20473223 